\title{
GIS-Based Rockfall Susceptibility Zoning in Greece
}

\author{
Charalampos Saroglou \\ Department of Geotechnical Engineering, School of Civil Engineering, National Technical University of Athens, \\ 15773 Athens, Greece; saroglou@central.ntua.gr
}

Received: 19 February 2019; Accepted: 2 April 2019; Published: 8 April 2019

check for updates

\begin{abstract}
The assessment of rockfall risks on human activities and infrastructure is of great importance. Rock falls pose a significant risk to (a) transportation infrastructure, (b) inhabited areas, and (c) Cultural Heritage sites. The paper presents a method to assess rockfall susceptibility at national scale in Greece, using a simple rating approach and Geographic Information Systems (GIS) techniques. An extensive inventory of rockfalls for the entire country was compiled for the period between 1935 and 2019. The rockfall events that were recorded are those which have mainly occurred as distinct rockfall episodes in natural slopes and have impacted human activities, such as roads, inhabited areas, and archaeological sites. Through a detailed analysis of the recorded data, it was possible to define the factors which determine the occurrence of rockfalls. Based on this analysis, the susceptibility zoning against rockfalls at the national scale was prepared, using a simple rating approach and GIS techniques. The rockfall susceptibility zoning takes into account the following parameters: (a) the slope gradient, (b) the lithology, (c) the annual rainfall intensity, (d) the earthquake intensity, and (e) the active fault presence. Emphasis was given on the study of the earthquake effect as a triggering mechanism of rockfalls. Finally, the temporal and spatial frequency of the recorded events and the impact of rockfalls on infrastructure assets and human activities in Greece were evaluated.
\end{abstract}

Keywords: rockfall; susceptibility; GIS; rainfall; earthquake; fault; inventory

\section{Introduction}

The assessment of rockfall risks on human activities and infrastructure is of great importance. Rock falls pose a significant risk to (a) transportation infrastructure, (b) inhabited areas, and (c) Cultural Heritage sites. The main triggering factors are rainfall, earthquakes, and thermal expansion and contraction. Geological assessment leads to accurate prediction of the outbreak of such events, explains its mechanism of occurrence, and assists in the effective design of protection measures.

In the last decade, Geographic Information Systems (GIS) were used for creating spatial models of potential hazard zonation maps for civil engineering and protection purposes by Mason and Rosenbaum (2002), Mancini et al. (2010), and Calvello et al. (2013) [1-3]. Several authors have presented the important role of GIS in hazard assessment and mitigation; these include Carrara et al. (1991), Barredo et al. (2000), Fernandez et al. (2003), Kolat et al. (2006), Yilmaz and Yildirim (2006), Nandi and Shakoor (2009), Paulin et al. (2014) [4-10], and others.

Susceptibility is the likelihood that an event will occur in a specific area based on the local terrain conditions (Brabb, 1984) [11]. The susceptibility describes the predisposition of an area to be affected by a given future event and results in an estimate of where rockfalls are likely to occur (Guzzetti 2006) [12]. According to Ferrari et al. (2016) [13], susceptibility can be assessed by: (a) geomorphological mapping, (b) empirical and semi-empirical rating systems, (c) statistical analyses, and (d) deterministic methods. The resulting susceptibility maps illustrate the predisposition towards instability of a slope or area. According to Fell et al. (2008) [14], rockfall susceptibility may be assessed based on either a 
qualitative or quantitative approach. The qualitative approach is based on either field geomorphologic analysis or the combination/overlying of index maps with or without weighting. In the present study, a semi-empirical rating was performed using overlaying of index maps without weighting.

Chau et al. (2003) and Chau et al. (2004) [15,16] presented a rockfall susceptibility map based on a rockfall inventory for Hong Kong using GIS-based techniques at the national level. Carman et al. [17] (2011) prepared a similar map for Slovenia. Trigila et al. (2013) [18] have presented landslide susceptibility mapping at the national scale in Italy using the Italian landslide inventory. Günther et al. (2013) [19] have presented landslide susceptibility assessment for Europe. In Greece, Koukis et al. (2005) and Sabatakakis et al. (2013) [20,21] proposed a landslide hazard zonation and a landslide susceptibility zonation using a landslide inventory derived from historical archives. Antoniou \& Lekkas (2010) [22] prepared a rockfall susceptibility map for Santorini Island in Greece using GIS methods. From the pertinent literature review, it is evident that there is no rockfall susceptibility zonation available in Greece.

The geological structure of Greece (frequent occurrence of rock formations, existence of faults and intense fracturing of rockmasses), the steep topography, and its high seismicity, contribute to the outbreak of rockfalls. During the last decades, rockfalls in Greece have become a frequent phenomenon due to intense rainfall events, earthquakes, and the extension of human activities in mountainous areas. Earthquake-triggered rockfalls were specifically investigated in the present study since historical and recent earthquakes in Greece have triggered a significant number of rockfalls, as reported by Papazachos \& Papazachou (1997), Pavlides \& Caputo (2004), Ambraseys \& Jackson (1990), and Saroglou (2013) [23-26]. More recently, Papathanassiou et al. (2013) [27] investigated the earthquake-induced instabilities in Lefkada Island and Zygouri \& Koukouvelas (2015) [28] have studied the evolution of rockfalls triggered by earthquakes in northern Peloponnese. Saroglou et al. (2017) [29] studied the coseismic rockfalls during Lefkada (2015) and Cephallonia (2014) earthquakes and Saroglou et al. (2018) [30] back-analyzed a coseismic rockfall trajectory of the Lefkada 2015 earthquake using UAV-based mapping.

The paper presents an extensive inventory of rockfalls for the period between 1935 and 2019 with events which have mainly occurred in natural slopes and have impacted human activities, such as roads, inhabited areas, and archaeological sites. Rockfalls that have occurred in man-made slopes were not taken into account in the present inventory. The paper also presents a method to assess rockfall susceptibility of natural slopes at national scale in Greece, using a simple rating approach and GIS techniques. The susceptibility map was based on simple rating of specific factors: (a) slope gradient, (b) lithology, (c) rainfall intensity, (d) earthquake intensity, and (e) active fault presence. These factors were selected based on the analysis and evaluation of the rockfall data recorded in the inventory of main rockfall events in Greece between 1935 and 2019. The importance of each factor in relation to the occurrence of rockfalls was investigated.

In the next sections, the rockfall inventory is first presented followed by the susceptibility assessment using GIS. The spatial distribution of rockfall events is evaluated in comparison to the susceptibility map.

\section{Rockfall Inventory}

A rockfall inventory was created for Greece for the period between 1935 and 2019. Sixty (60) rockfalls events were recorded in forty-three (43) sites, as presented in the national map of Greece shown in Figure 1.

The rockfall events that were recorded are those which have mainly occurred as distinct rockfall episodes in natural slopes and have impacted human activities, such as roads, inhabited areas, and archaeological sites. Rockfalls, which have occurred in man-made slopes (mainly along highways), were not taken into account in the present inventory.

The following data were recorded for each rockfall episode: (a) Location, (b) Coordinates, altitude, (c) Type of site (roadway, inhabited area, archaeological site), (d) Date (s) of rockfall event(s), 
(d) Triggering mechanism (rainfall, earthquake, other), (e) Fault presence (slope scarp), (f) Geological formation, (g) Rock mass type, degree of fracturing, (h) Slope height, (i) Slope angle, (j) Block size of fallen blocks, (k) Impact (type of affected site), (l) Presence of vegetation (forest etc.), (m) Energy level.

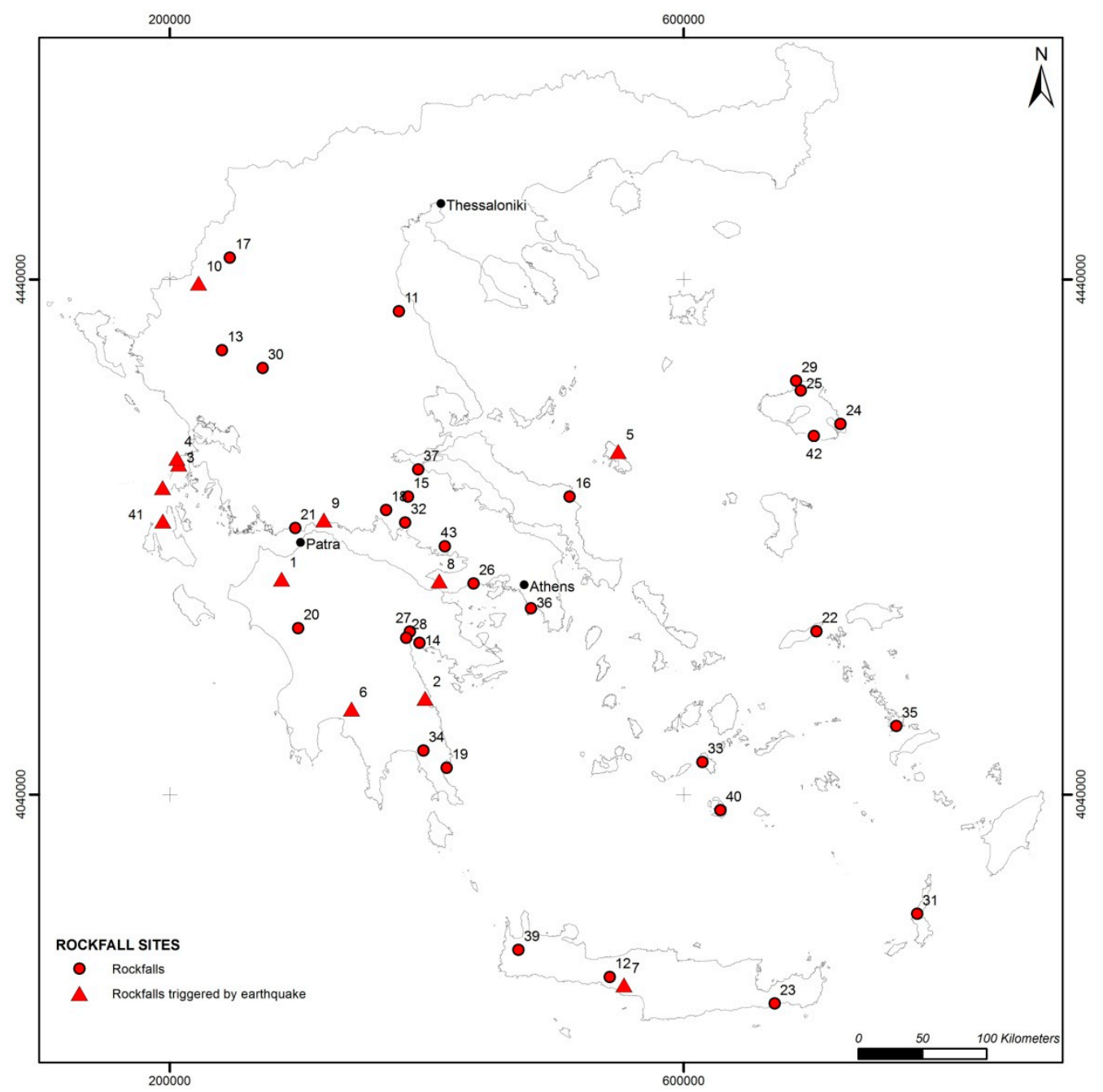

Figure 1. Inventory of recorded rockfall events in Greece.

The main recorded parameters of these events are given in Table 1. More details for this rockfall inventory and sources of records were reported in Saroglou (2013) [26].

In some sites, more than one event has occurred and thus it is possible to predict the return period of rockfalls in these cases.

Koukis \& Ziourkas (1991) [31] and Koukis et al. (2005) [20] presented a landside frequency zonation map for Greece. The relative frequency of rockfalls, expressed in cases per surface area, was $11 \%$. The maximum frequency of landslides is along the Pindos geotectonic zone, where a large number of slope instabilities occur in the flysch formation in the form of soil type or composite failures (rotational, translational etc.). Based on the present study, the maximum frequency of rockfalls is encountered in western and central Greece.

Rockfalls are generally more frequent in mountainous areas in Greece, where the slope angle is greater than 50 degrees. This is evidenced by the higher occurrence of events in mountainous areas of Greece, such as Pindos and Parnassos Mountain (Figure 1). Rockfalls also occur in low to medium altitude areas where slopes with steep morphology exist, usually related to fault scarps, such as the case of Kakia Scala (Table 1, site 26), Klokova (site 21), and Monemvasia promontory (site 19). 
Table 1. Main data of recorded rockfalls in Greece.

\begin{tabular}{|c|c|c|c|c|c|c|c|c|}
\hline Id & Location & Type & Date & Trigger & Rock Type & Fault Scarp & Block $\left(\mathrm{m}^{3}\right)$ & Impact \\
\hline 1 & Santomeri, Achaia & $\mathrm{D}$ & $8 / 6 / 2008$ & $\mathrm{E}(6.5)$ & $\mathrm{L}$ & $\mathrm{Y}$ & 4 & DH \\
\hline 2 & Leonidio, Tiros & $\mathrm{R}$ & $6 / 1 / 2008$ & $\mathrm{E}$ & $\mathrm{L}$ & Y & $<1$ & $\mathrm{RC}$ \\
\hline 3 & Drimonas, Lefkada & $\mathrm{D} / \mathrm{R}$ & $14 / 8 / 2003$ & $\mathrm{E}(6.4)$ & $\mathrm{L}$ & $\mathrm{Y}$ & $<1$ & $D R$ \\
\hline 4 & Lefkada, Ag.Nikitas & $\mathrm{D} / \mathrm{R}$ & $14 / 8 / 2003$ & $\mathrm{E}(6.4)$ & $\mathrm{L}$ & y & 13.7 & PDR \\
\hline 4 & Lefkada, Ag.Nikitas & $\mathrm{D} / \mathrm{K}$ & $19 / 11 / 2015$ & $\mathrm{E}(6.5)$ & $\mathrm{L}$ & $Y$ & 2 & HLL \\
\hline 5 & Skyros Island & A & $26 / 7 / 2001$ & $\mathrm{E}(5.8)$ & $\mathrm{L}$ & Y & $1-2$ & $\mathrm{DC}$ \\
\hline 6 & $\begin{array}{l}\text { Ladas, Eleochori, } \\
\text { Poliani, Kalamata }\end{array}$ & $\mathrm{D}$ & 13/9/1986 & $\mathrm{E}(6.2)$ & $\mathrm{L}$ & & $<1$ & $\mathrm{PDH}$ \\
\hline 7 & $\begin{array}{l}\text { Heraklion (Pitsidia, } \\
\text { Akoumia) }\end{array}$ & $\mathrm{D}$ & $14 / 5 / 1959$ & $\mathrm{E}(6.3)$ & $\mathrm{L}$ & Y & $<1$ & DH \\
\hline 8 & Geraneia Mt. & & $24 / 2 / 1981$ & E (6.3) & $\mathrm{L}$ & Y & & \\
\hline 9 & Itea, Monastiraki & $\mathrm{R}$ & $18 / 1 / 2010$ & $\mathrm{E}(5.1)$ & $\mathrm{L}$ & Y & $<1$ & DR \\
\hline 10 & Konitsa, Ioaninna & $\mathrm{D} / \mathrm{A}$ & 8/1998 & E & LA & & 2 & $\mathrm{DH}$ \\
\hline 11 & Tempi Valley & $\mathrm{R}$ & $\begin{array}{l}17 / 12 / 2009 \\
2004,1977^{1}\end{array}$ & ND & M & & $0.5-5,50$ & HLL, RC \\
\hline 12 & Kourtaliotis gorge & $\mathrm{R}$ & $4 / 3 / 2012$ & $\mathrm{R}$ & $\mathrm{L}$ & Y & 1 & DR \\
\hline 13 & Pramanta -Ioannina & $\mathrm{R}$ & $9 / 3 / 2004$ & ND & $\mathrm{L}$ & $\mathrm{Y}$ & $<1$ & DR \\
\hline 14 & Acronafplia & A & $1 / 2010$ & ND & $\mathrm{L}$ & & 0.5 & $\mathrm{~V}$ \\
\hline 15 & Tithorea, Parnassos & $\mathrm{D}$ & $\begin{array}{l}19 / 12 / 2010 \\
1999,1957\end{array}$ & ND & $\mathrm{L}$ & & 10 & DH \\
\hline 16 & Oksilithos, Kymi & $\mathrm{R}$ & $13 / 8 / 2008$ & ND & MS & & 1.5 & HI \\
\hline 17 & Eptachori, Kastoria & $\mathrm{D}$ & $\begin{array}{c}1935,51, \\
68,70,87,93,94\end{array}$ & $\mathrm{R}$ & M & Y & $336^{2}$ & $\mathrm{DH}$ \\
\hline 18 & Delfi ancient site & A & $2003,09^{1}$ & $\mathrm{R}$ & $\mathrm{L}$ & & 8 & V \\
\hline 19 & Monemvasia & A & $2003,2010^{1}$ & $\mathrm{R}$ & $\mathrm{L}$ & $\mathrm{Y}$ & 2 & $\mathrm{DH}, \mathrm{V}$ \\
\hline 20 & Anc. Olympia & $\mathrm{R}$ & $22 / 1 / 2013$ & $\mathrm{R}$ & $\mathrm{L}$ & & 0.5 & DR \\
\hline 21 & Klokova Mt. & $\mathrm{R}$ & $16 / 11 / 2012$ & ND & $\mathrm{L}$ & & $1-2$ & DR \\
\hline 22 & Therma Ikaria & $\mathrm{D}$ & 10/1978 & ND & M & $\mathrm{Y}$ & 1 & PDH \\
\hline 23 & Ag. Fotia, Crete & $\mathrm{R}$ & - & ND & $\mathrm{S}$ & & $<1$ & DR \\
\hline 24 & Taxiarches, Lesvos & $\mathrm{D}$ & $1963,3 / 11 / 09$ & ND & M & Y & 1 & DH \\
\hline 25 & Mythimna, Lesvos & A & 2001 & $\mathrm{R}$ & A & & 0.3 & ND \\
\hline 26 & Kakia Scala & $\mathrm{R}$ & $20 / 11 / 2000$ & $\mathrm{R}$ & $\mathrm{L}$ & $\mathrm{Y}$ & 0.5 & HLL \\
\hline 27 & Argos Castle & A & 1987 & ND & $\mathrm{L}$ & & & $\mathrm{D}$ \\
\hline 28 & Kefalari, Argos & $\mathrm{D}$ & $20 / 4 / 2012$ & ND & $\mathrm{L}$ & $\mathrm{Y}$ & 0.1 & HLL \\
\hline 29 & Stypsi, Lesvos & $\mathrm{D}$ & 1963,1977 & $\mathrm{R}$ & A & & $0.5-3.0$ & DH \\
\hline 30 & Orliagas, Ziakas & $\mathrm{D} / \mathrm{R}$ & & ND & $\mathrm{L}$ & Y & 1 & ND \\
\hline 31 & Carpathos, Akropoli & $\mathrm{D}$ & - & ND & $\mathrm{L}$ & & & - \\
\hline 32 & Vageni Distomo & $\mathrm{D} / \mathrm{R}$ & & ND & C & $\mathrm{Y}$ & 40 & PDR \\
\hline 33 & Kalymnos & $\mathrm{D}$ & $12 / 2002$ & $\mathrm{R}$ & $\mathrm{L}$ & & 4 & PDH \\
\hline 34 & Molaoi, Lakonia & $\mathrm{D}$ & $2 / 2003$ & $\mathrm{R}$ & CA & & $1-2$ & PDH \\
\hline 35 & Chora, Ios & $\mathrm{D}$ & - & ND & $\mathrm{S}$ & & 1 & PDH \\
\hline 36 & Vouliagmeni, Attica & $\mathrm{D}$ & $1 / 1982$ & ND & $\mathrm{L}$ & $\mathrm{Y}$ & $1-2$ & \\
\hline 37 & Kamena Vourla & $\mathrm{D}$ & $27 / 8 / 2012$ & ND & $\mathrm{L}$ & & 1 & DH \\
\hline 38 & Nea Pefki, Trikala & $\mathrm{R}$ & $20 / 10 / 2010$ & $\mathrm{R}$ & $\mathrm{S}$ & & $<1$ & DR \\
\hline 39 & Topolia, Chania & $\mathrm{R}$ & $23 / 2 / 2012$ & $\mathrm{R}$ & $\mathrm{L}$ & Y & 0.5 & FB \\
\hline 40 & Santorini & $\mathrm{D}$ & 2011 & $\mathrm{R}$ & $\mathrm{P}$ & & 0.5 & HLL \\
\hline 41 & $\begin{array}{l}\text { Myrtos, Cephallonia } \\
\text { Island }\end{array}$ & $\mathrm{O}$ & $17 / 1 / 2014$ & E (6.1) & $\mathrm{L}$ & Y & 50 & DR \\
\hline 42 & Lesvos, Plomari & $\mathrm{D}$ & $24 / 11 / 2018$ & $\mathrm{R}$ & SG & & 10 & DH \\
\hline 43 & Alyki, Voiotia & $\mathrm{D}$ & $27 / 1 / 2019$ & $\mathrm{R}$ & $\mathrm{L}$ & & 70 & DH \\
\hline
\end{tabular}

${ }^{1}$ More rockfall events exist, which are not presented here, ${ }^{2}$ the largest rock block, 15 smaller rocks have fallen in this site, Type: $\mathrm{R}=$ Roadway, $\mathrm{D}=$ Domestic, $\mathrm{A}$ : Archeological, $\mathrm{O}=$ other (touristic area, coast), Trigger: $\mathrm{R}=$ rainfall, $\mathrm{E}=$ Earthquake, $\mathrm{ND}=$ Not defined, Rock type: $\mathrm{L}=$ limestone, $\mathrm{M}=$ marble, $\mathrm{CA}=\mathrm{Calcitic}$ agglomerate, $\mathrm{LA}=$ Limestone agglomerate, $\mathrm{C}=$ conglomerates, $\mathrm{S}=$ sandstone, $\mathrm{M}=$ marls, $\mathrm{MS}=$ marls $/$ sandstones, SG $=$ Schist/gneiss, $A=$ Andesite, $P=$ Pyroclastics, Fault Scarp: $\mathrm{Y}=$ yes, Impact: HLL $=$ Human loss, HI $=$ Human injury, V = Potential impact on visitors, damage to archaeological site, $\mathrm{DH}=$ Damage to houses, $\mathrm{PDH}=\mathrm{Potential}$ house damage, $\mathrm{RC}=$ Roadway closure, $\mathrm{DR}=$ Damage on roadway, $\mathrm{PDR}=$ Potential roadway damage, $\mathrm{FB}=$ fall on moving bus, $\mathrm{DC}=$ Damage on cars, $\mathrm{ND}=$ No damage.

\section{Evaluation of the Rockfall Inventory}

\subsection{Geological Framework and Rockfalls in Greece}

The most frequent geological formation encountered in the study areas is limestone (frequency of occurrence equal to $64 \%$ ). The occurrence of the rocks forming the slopes, as recorded in the database, is presented in Figure 2a. The most frequent geological formation encountered in the rockfall study 
areas is limestone (with a frequency equal to $64 \%$ ), while in fewer sites, marble (7\%), marls/sandstones $(7 \%)$, schists/gneisses (3\%), and igneous rocks $(8 \%)$ are encountered.

Generally, limestones are found broken to heavily broken, especially when in the vicinity of faults, resulting in blocky rock masses. Rockfalls are favored in blocky or very blocky rock masses, since medium to large rock blocks are formed by intersecting discontinuities and can be relatively easily detached by the action of water or seismic loading.

In a large number of sites, scree is present at the foot of the slopes. The presence of a scree slope at the base of the rock cliff suggests slope raveling activity. According to Sartori et al. (2003) [32], this activity can be linked to the progressive failure of the rock cliff, but can also be a precursory event of larger rockfalls. Marquínez et al. (2003) [33] presented a rockfall activity index defined as the ratio At/Ar, which correlates with the ability of a certain lithology to produce rockfalls. The index is the ratio of the cartographic surface of the recent talus scree (At) to that of the rocky slope acting as source area (Ar). Dorren \& Seijmonsbergen (2003) [34] assigned rockfall susceptibility categories to geological formations according to their nature and ability to produce rocks blocks. They considered limestone to have high susceptibility, while schists, slates, marls, and sandstones low to medium. The block size of the fallen blocks ranges between 0.5 and $50 \mathrm{~m}^{3}$ with an exception of Eptachori rockslide. The blocks size is less than $1 \mathrm{~m}^{3}$ in 22 sites and between 1 and $5 \mathrm{~m}^{3}$ in eight sites, as presented in Figure $2 \mathrm{~b}$.

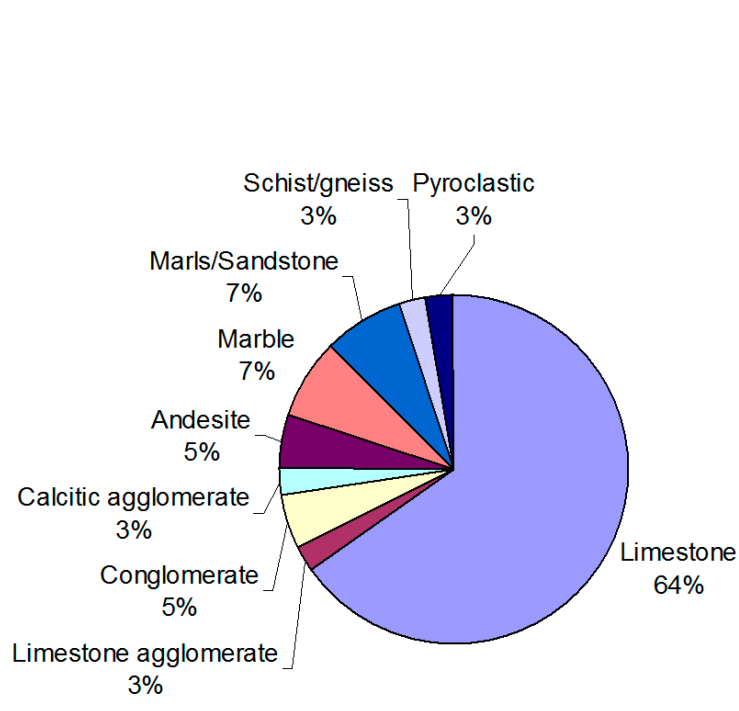

(a)

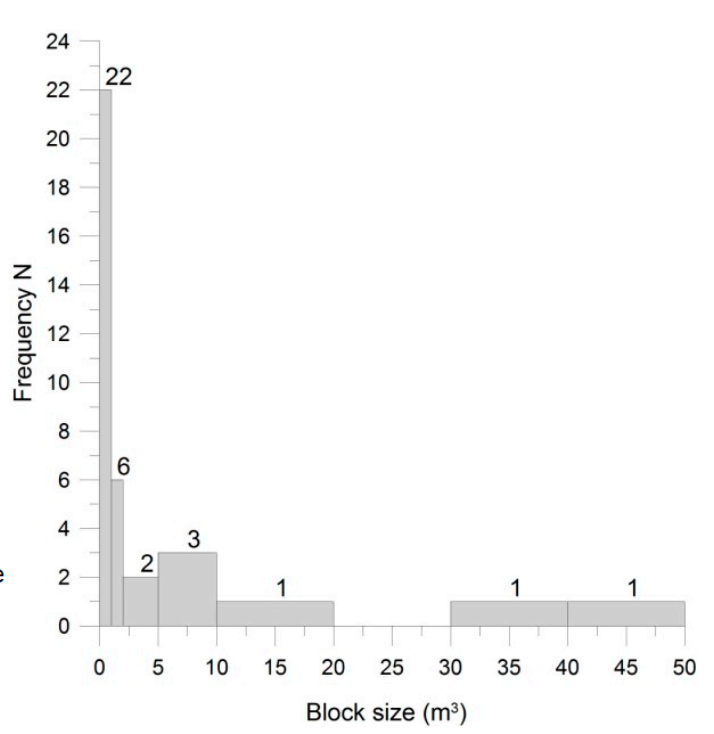

(b)

Figure 2. (a) Lithology in areas of rockfall events, (b) Frequency of block size of fallen rocks.

\subsubsection{Temporal-Spatial Frequency of Rockfalls}

Based on the recorded data, it was possible to define the frequency of rockfalls for the considered time period. The average frequency is one event every 1.3 years, considering the total number of events, irrespective of the rockfall magnitude. For rockfalls with volume of blocks less than $2.5 \mathrm{~m}^{3}$ the return period is 2.8 years, while for events with volume greater than $10 \mathrm{~m}^{3}$, the return period is 16 years. The frequency of rockfalls is shown in Figure 3. It is noted that the number of rockfalls has increased in the 2000-2010 and 2010-2020 decades, which may be attributed to reasons related with climate change (more extreme weather events) or increase of knowledge of rockfall outbreaks through improvement of communication systems. 


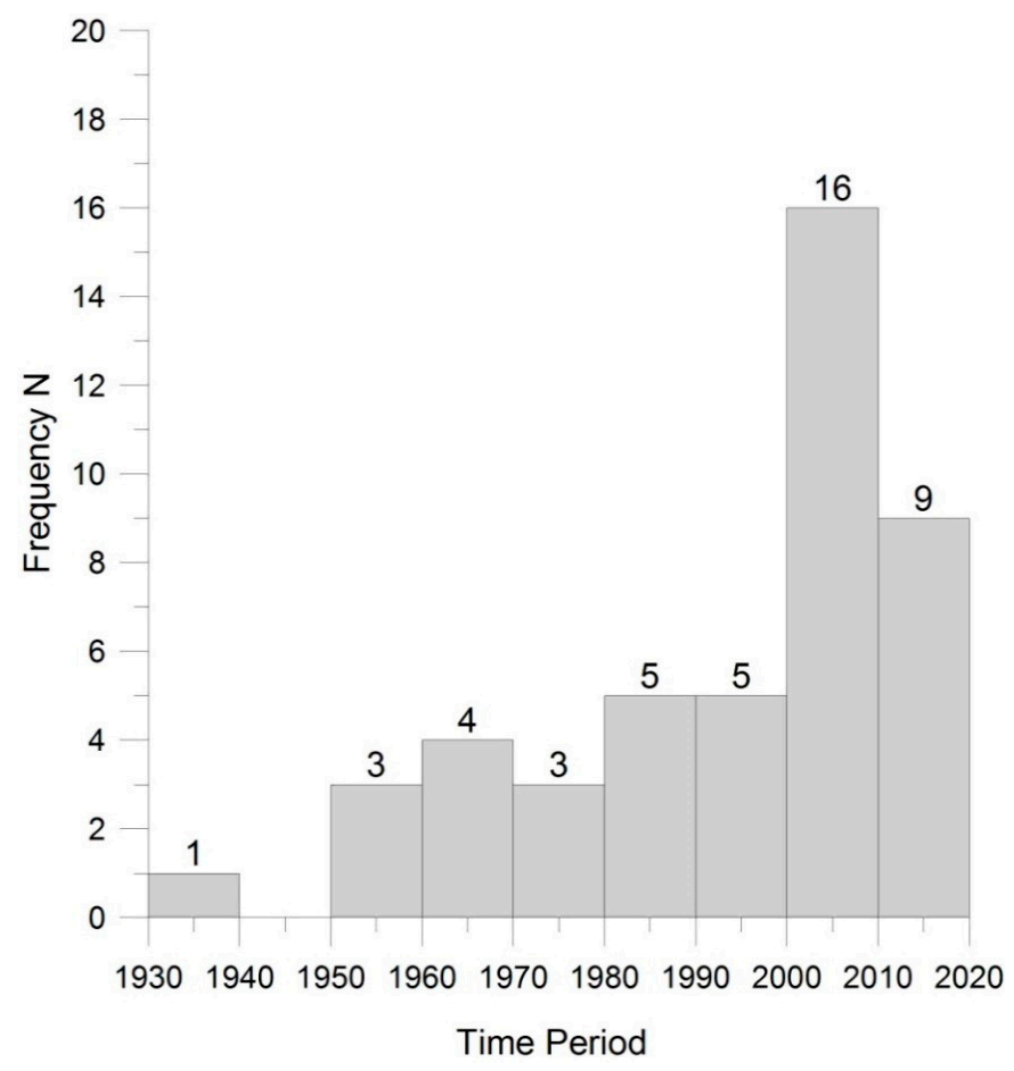

Figure 3. Frequency of rockfalls for the period between 1935 and 2019.

\subsubsection{Triggering Mechanisms}

According to the evaluation of the recorded data, the main triggering mechanism of rockfalls is rainfall. Thirteen (13) rockfall events were triggered by rainfall (frequency equal to 33\%) and one (1) event by a snowfall. An increase in the number of rockfalls, triggered due to rainfall, has occurred during the last decade mainly due to the occurrence of extreme weather events during the winter periods. This is evidenced, by the occurrence of eighty-six (86) instability phenomena ( $5 \%$ of these were rockfalls) in 2010 (Nikolaou et al., 2011) [35], 95\% of which were triggered by intense rainfall during February and the November-December period.

The second most important triggering mechanism was seismic loading as twelve (12) rockfall events were triggered during earthquakes (frequency equal to $25 \%$ ).

\subsubsection{Coseismic Rockfalls in Greece}

Earthquakes, which triggered large rockfall events, are those during Alkyonides (1981) and Kalamata (1986) earthquakes, in Skyros Island (2001), in Achaia (2008), in Cephallonia Island (2014), and in Lefkada Island (2003 and 2015). During some of these earthquakes, such as the ones in Kalamata and Achaia, rockfalls occurred along reactivated fault scarps.

The most significant coseismic rockfalls in Greece since 1980 are presented in Table 2, where the location, the date, the magnitude $\left(\mathrm{M}_{\mathrm{w}}\right)$ of the earthquake, and the distance of the rockfall site from the earthquake epicenter are reported. 
Table 2. Main coseismic rockfalls in Greece.

\begin{tabular}{cccccc}
\hline No. & Location & Date & Magnitude (Mw) & Rockfall Site & Distance (km) \\
\hline 1 & Gerania, Korinthos & $13 / 9 / 1986$ & 6.7 & Alkyonides & 27 \\
2 & Kalamata & $8 / 1998$ & 6 & Kalamata-Sparti road & 6.5 \\
3 & Konitsa & $14 / 8 / 2003$ & 5.7 & Eptachori & 36.8 \\
4 & Skyros & $24 / 2 / 1981$ & 6.5 & Skyros castle & 20.5 \\
5 & Lefkada & $26 / 7 / 2001$ & 6.3 & Ag. Nikitas & 7 \\
6 & Achaia & $8 / 6 / 2008$ & 6.4 & Santomeri & 5.9 \\
7 & Cephallonia & $26 / 01 / 2014$ & 5.9 & Myrtos & 16.4 \\
8 & Lefkada & $11 / 2015$ & 6.4 & Ag. Petros & 2.8 \\
\hline
\end{tabular}

The effect of earthquakes on the occurrence of rockfalls is twofold: (a) the magnitude and epicenter distance of an earthquake define whether an unstable block will be detached from a rock slope and (b) the peak ground velocity exerted by an earthquake determines the displacement magnitude of a rock block. Hazard assessment methodologies against earthquake-triggered rockfalls have been applied by Gorum et al. (2011) [36] for the Wenchuan earthquake-induced landslides, by Wasowski \& Del Gaudio (2000) [37] in Italy, by Rodriguez-Peces et al. (2011) [38] in Spain, and Marzorati et al. (2002) [39], who produced a rockfall susceptibility map triggered by earthquakes in the Umbria and Marche region in Italy.

Keefer (1984) and Rodriguez et al. (1999) [40,41] developed a magnitude-source distance diagram for landslides, which can also be applied to rockfalls. This diagram (Keefer, 1984) [40] is presented in Figure 4, in which the main coseismic rockfalls from Greece are plotted. The dashed curve presents the maximum distances from fault rupture zones at which disrupted slides and falls have been observed worldwide. Magnitude-distance relations for earthquake-induced landslides in Greece have been proposed by Papadopoulos \& Plessa (2000) [42]. More recently, Chousianitis et al. (2016) [43] performed an assessment of the earthquake-induced landslide hazard in Greece, investigating the areal intensity and spatial distribution of slope resistance demand.

The triggering of rockfalls for the events whose epicentral distances plot above the threshold curve is unlikely.

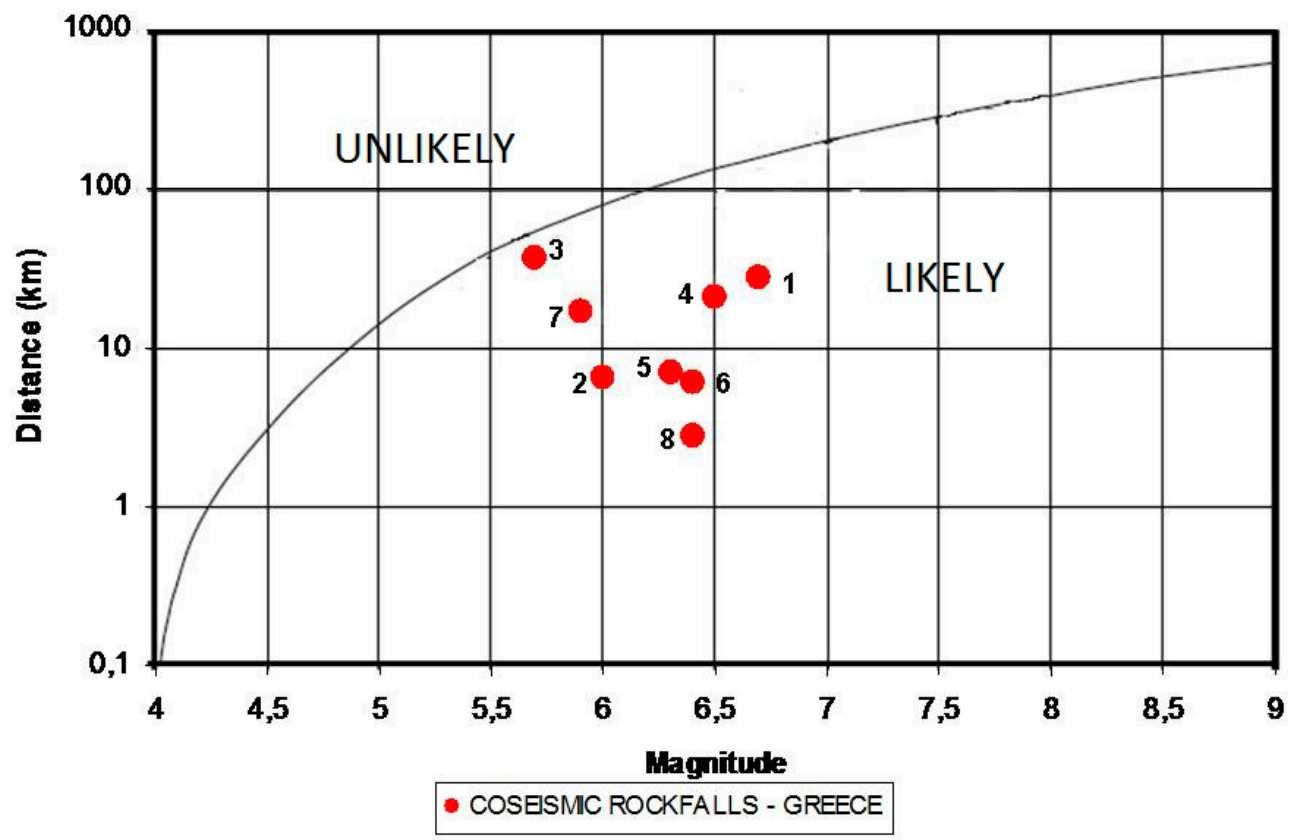

Figure 4. Magnitude-source distance diagram of coseismic rockfalls in Greece. 
It is obvious that all the coseismic rockfall events in Greece plot well below the curve suggested by Keefer (1984) [40]. The magnitude of earthquakes that triggered rockfalls is between $\mathrm{M}_{\mathrm{W}}=5.7$ and 6.7, while the maximum distance from the epicenter to a reported rockfall was $36.8 \mathrm{~km}$.

\subsubsection{Impact of Rockfalls in Greece}

Based on the analysis of the data, the main impact of rockfalls is damage and temporary closure of roadways (frequency equal to 32\%) and secondly, damage to houses (frequency equal to $20 \%$ ). The percentage of potential damage to roadways and houses is $5 \%$ and $13 \%$, respectively. The potential damage is defined when a rockfall event poses a direct impact to houses or roadway, but has not impacted them already. Additionally, the percentage of loss of human life is $11 \%$, which is considered exceptionally high. Furthermore, the frequency of potential impact on visitors and damage to archaeological sites is equal to $11 \%$.

The most known and studied events, which have occurred along highways and other roads, are those of Tempi highway (shown in Figure 5b), Kakia Skala (site 26), and Klokova area (site 21). Significant rockfall events impacting roads have taken place in Ag. Nikitas in Lefkada island during the earthquakes in 2003 and 2015 (Figure 5b).

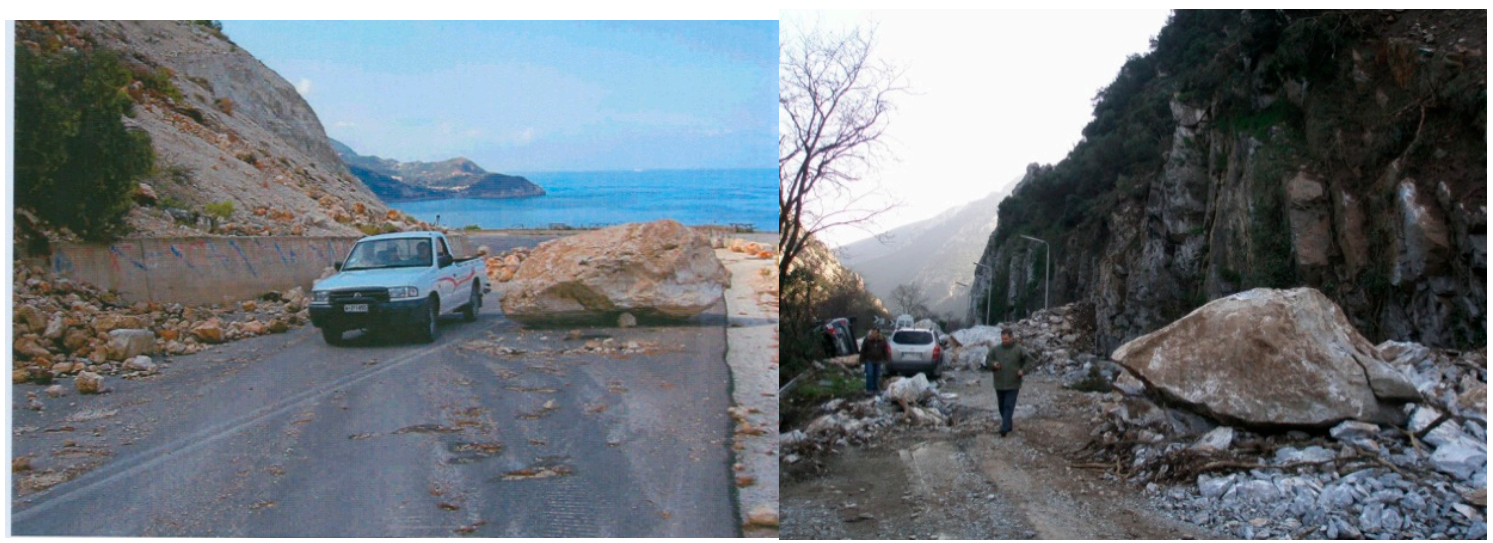

a)

b)

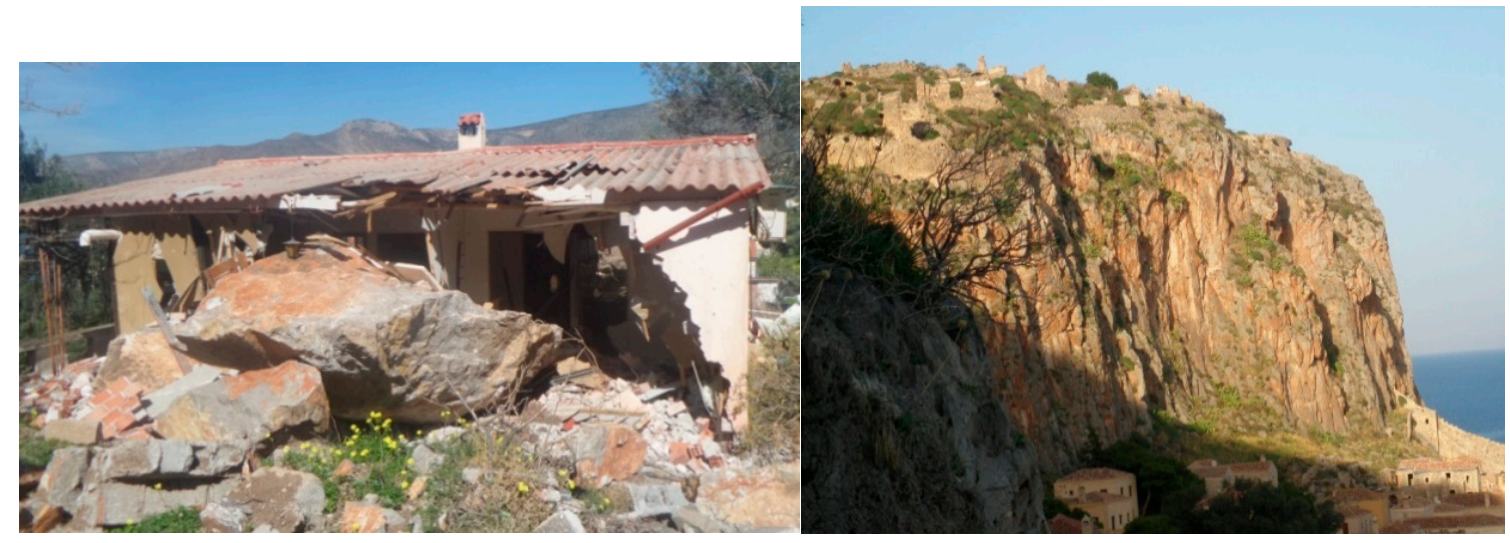

C)

d)

Figure 5. Impact of main rockfall events: (a) on local road network in Lefkada during 2003 earthquake (site 3) (b) on National Highway in Tempi valley in 2009 (site 11), (c) in Alyki village in 2019 (site 43), (d) in Monemvasia archaeological site (site 19). 
Recent events that affected inhabited areas are those in Eptachori in 1994 (site 17), in Skyros in 2001 (Marinos \& Tsiambaos, 2002) [44], Santomeri in 2008 (Koukouvelas et al., 2015 [45]), and Tithorea in 2010 (Saroglou et al., 2015) [46], Plomari in 2018 and Alyki village in 2019. Finally, a house was impacted by a rockfall during a $\mathrm{M}_{\mathrm{W}} 6.4$ earthquake in Lefkada in 2015, resulting in one casualty (Saroglou et al., 2018 [30]).

Sites of high risk in inhabited areas need to be identified in order to minimize rockfall risk. Additionally, there are a large number of rockfall incidents, which have occurred in archaeological sites. These pose a significant danger to tourists and visitors and affect the integrity of the monuments. Such an example is the archaeological site of Delphi (Christaras \& Vouvalidis, 2010) [47], where part of the archeological site was closed in 2009. Other affected cultural heritage sites are Mythimna castle (Marinos et al., 2002) [48] and Monemvasia castle (Saroglou et al., 2012) [49], as indicated in Figure 5d.

\section{Rockfall Susceptibility}

\subsection{Introduction}

In order to develop the rockfall susceptibility map, GIS techniques in combination with a simple rating approach were used. The main assessment factors were selected based on the evaluation of the recorded data presented earlier. These factors are the following: (1) slope gradient (2) lithology, (3) annual rainfall intensity, (4) earthquake intensity, and (5) active fault presence.

The proximity of a fault has been taken into account only as a qualitative parameter, since it relates to the formation of steep rock cliffs and increased degree of fracturing of rockmass, thus it can be connected to the susceptibility of a rock slope to rockfalls.

Based on these factors, thematic maps for each factor were generated. The rating approach for each factor is described in the following paragraphs.

\subsection{Susceptibility Factors}

\subsubsection{Slope Gradient}

Rock slope instabilities occur in steep slopes. The adopted cut off value for slope gradient, above which rock slope instability may occur, is $45^{\circ}$, by analogy with other approaches that give higher values to steeper slopes (Gupta et al., 1999; Meisina et al., 2001) [50,51].

Based on the inventory, the slope angle in the areas with rockfall events ranged between 45 and 90 degrees, while the average slope angle was 70 degrees.

In the present study, a value of 27 degrees was selected. If a value of $45^{\circ}$ were to be chosen, the potential rockfall prone areas would be very limited due to the small scale of the map used (1:500.000). The Digital Elevation Model (DEM) was provided by the Hellenic Military Geographical Service (HMGS) in the form of a 25-m density grid of elevation points. A DEM with a spatial resolution of $25 \mathrm{~m}$ was created in ARCGIS. The standard ArcView processing was used (Ballifard et al., 2003) [52], which is considered as more appropriate for rough surfaces. The rating for slope gradient is 1 for slopes with angle greater than $27^{\circ}$ and 0 for slope angle less than $27^{\circ}$. The slope map is presented in Figure 6. 


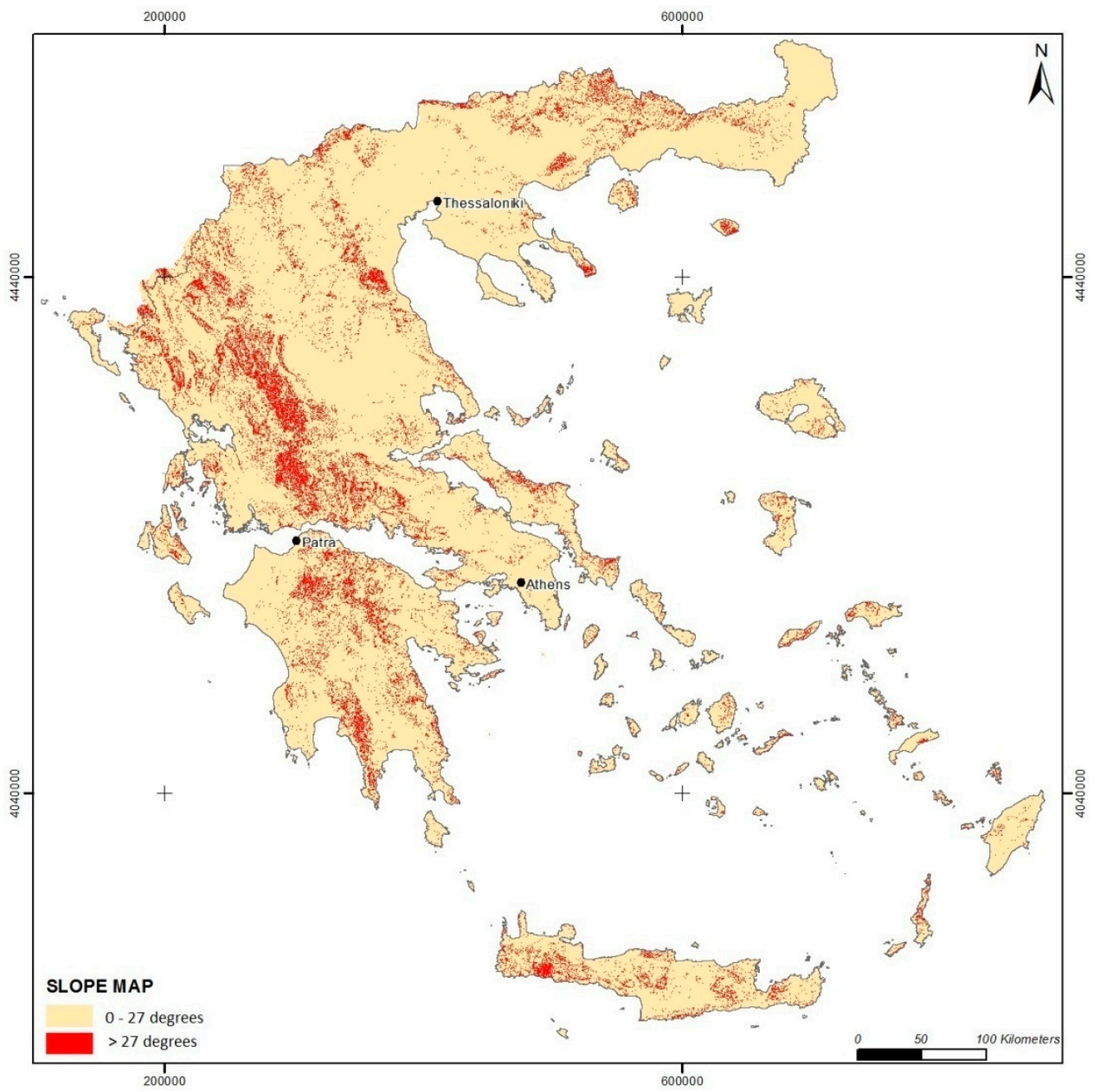

Figure 6. Slope map of Greece.

\subsubsection{Lithology}

Lithology is a significant factor of the occurrence of rockfalls, since it controls the overall behavior of the geological formation, the degree of fracturing; the permeability of the rockmass and in some occasions the steepness and height of the slope. Rockfalls are favored in blocky or very blocky rock masses, since medium to large rock blocks are formed by intersecting discontinuities and can be relatively easily detached by the action of water or seismic loading.

Dorren \& Seijmonsbergen (2003) [34] proposed a rockfall susceptibility of geological formations and assigned rockfall susceptibility categories to them according to their nature and ability to produce rock blocks. They considered that limestone has high susceptibility to generating rockfalls, while schists, slates, marls, and sandstones low to medium. Coe \& Harp (2007) [53] presented the influence of tectonic folding on rockfall susceptibility, suggesting that the presence of folds in limestone rocks increases the number of rockfall events. Fityus et al. (2013) [54] performed a detailed study on the significance of geological environment (mainly lithology and tectonic setting) on the morphology and size of potentially unstable blocks.

In the present study, the basic data used to generate the original geological map in vector format were obtained from the existing geological map of Greece published by the Institute of Geology and Mineral Exploration (scale 1:500.000). The main geological formations were grouped into eleven (11) categories based on their lithology, origin, and engineering geological behavior (Figure 7). These were rated with reference to their rockfall susceptibility, thus their ability to produce abundance of rock blocks based on the usual rockmass structure conditions and behavior encountered in these 
categories. The rating was also based on the evaluation of the rockfall inventory, presented earlier. The susceptibility rating of lithology is presented in Table 3.

The lithology classification map is presented in Figure 8.

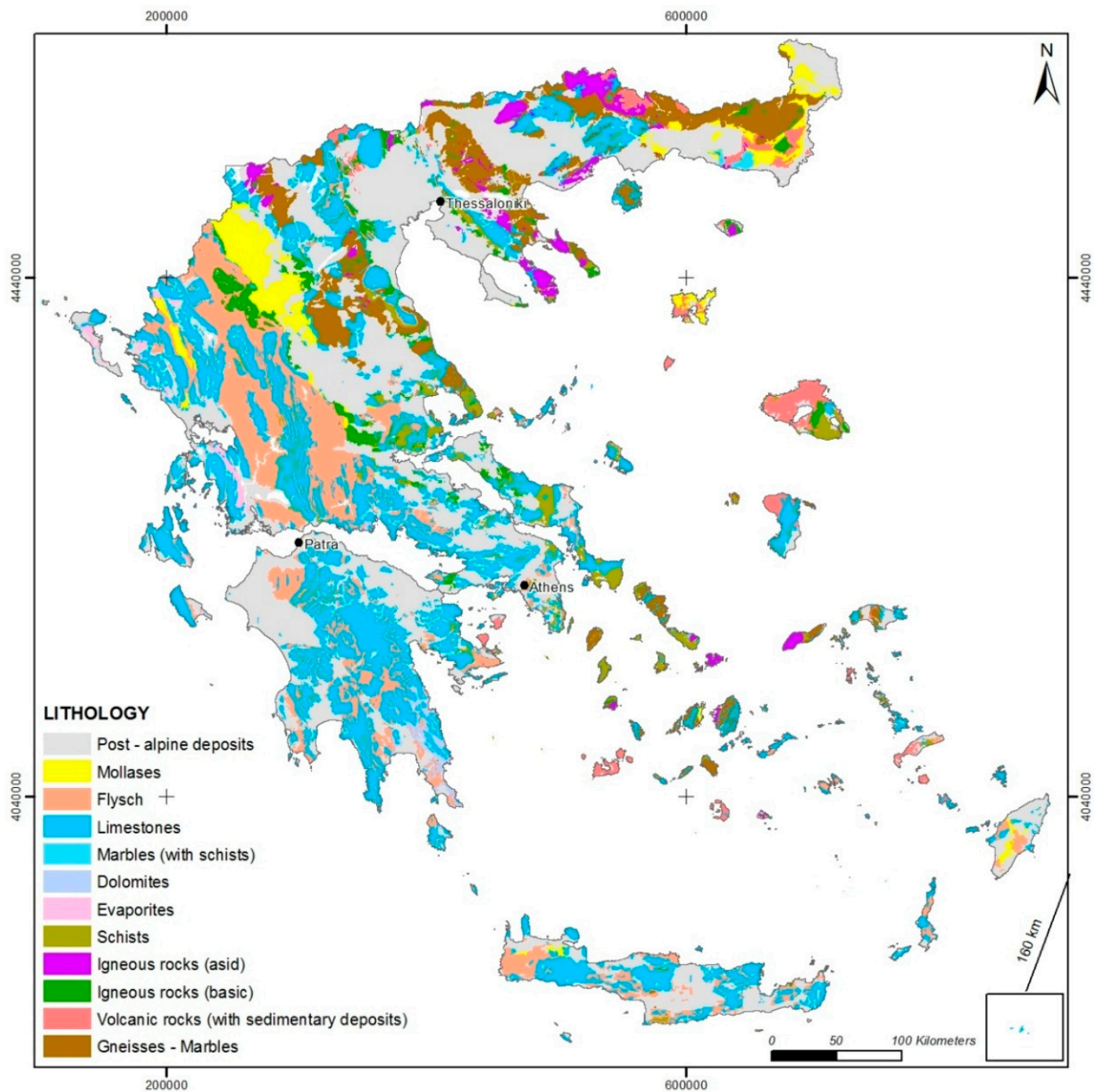

Figure 7. Main geological units encountered in Greece.

Table 3. Rating of lithology.

\begin{tabular}{ccc}
\hline Geological Formation & Rockfall Susceptibility & Class \\
\hline Postalpine (Marls, claystones, etc.) & Low & 3 \\
Gypsum & Low & 3 \\
Schists & Low & 3 \\
Molasse deposits & Moderate & 2 \\
Flysch & Moderate & 2 \\
Igneous rocks (granites etc.) & Moderate & 2 \\
Marble-Schist (alternations) & Moderate & 2 \\
Dolomites & High & 1 \\
Limestone & High & 1 \\
Volcanic sedimentary rocks & High & 1 \\
Gneiss-Marbles & High & 1 \\
\hline
\end{tabular}




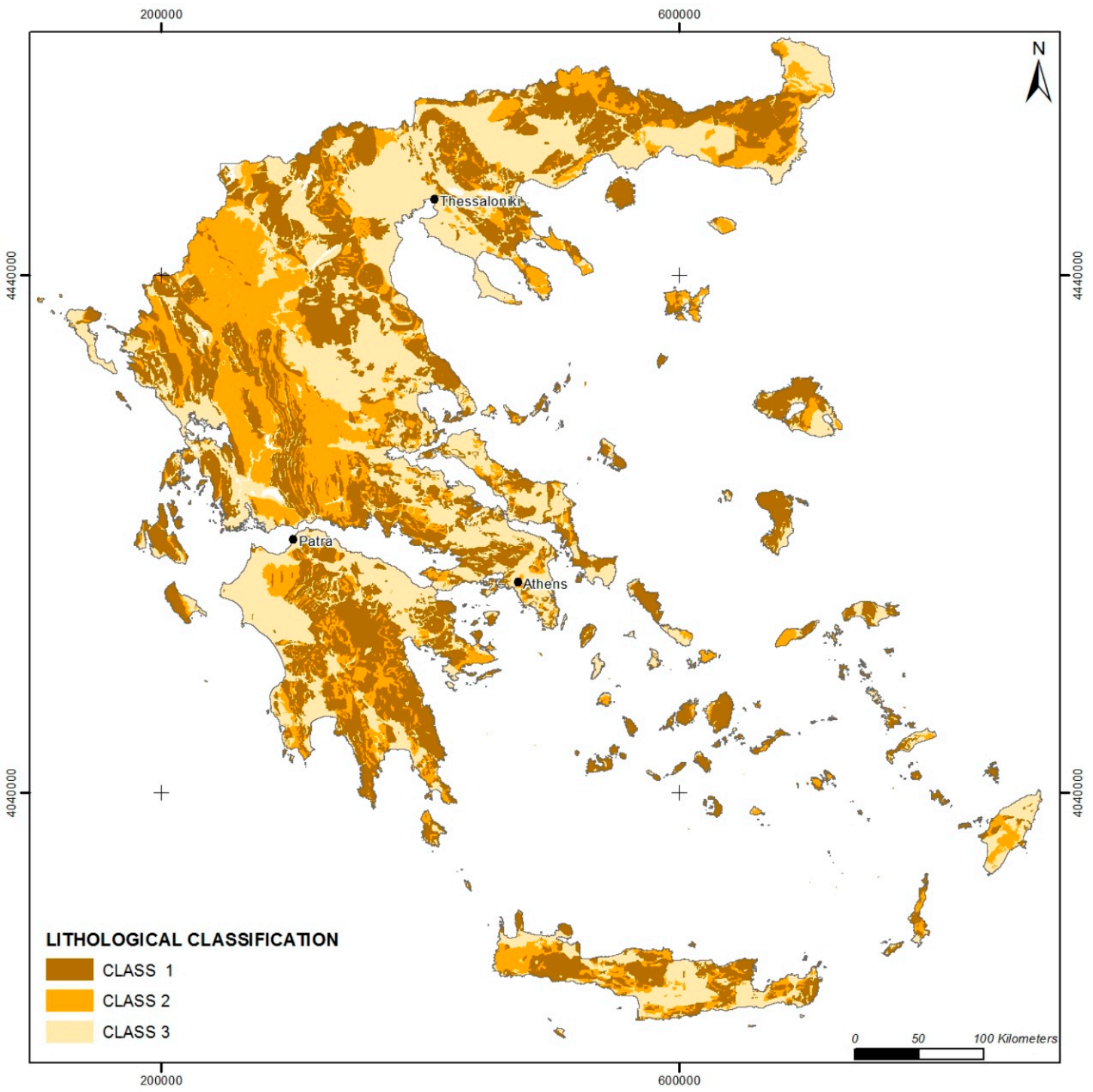

Figure 8. Thematic map of classification of lithology in Greece.

\subsubsection{Rainfall Intensity}

It has been established by many studies that rainfall intensity correlates well with the occurrence of rockfalls. Krautblatter \& Moser (2009) [55] proposed a nonlinear model coupling between rainfall and rockfall based on a 4-year monitoring in the Alps. In a number of studies, it is suggested that the maximum precipitation in a $24 \mathrm{~h}$ period for a particular return period (50 or 100 years) tends to correlate better with triggering of slope instability phenomena. This is based on the fact that high but regular rainfall tends not to saturate slopes, while lower but irregular rainfall does. Since the assessment is at a national scale, the annual precipitation was chosen for the correlation with rockfall events. A simple rating was proposed considering that rockfall susceptibility increases with annual rainfall intensity. The rating of rainfall intensity is shown in Table 4 . The annual precipitation map (Isohyetal contouring) was prepared at an original scale 1:500.000 (Institute of Geology and Mineral Exploration-IGME) and is presented in Figure 9. 


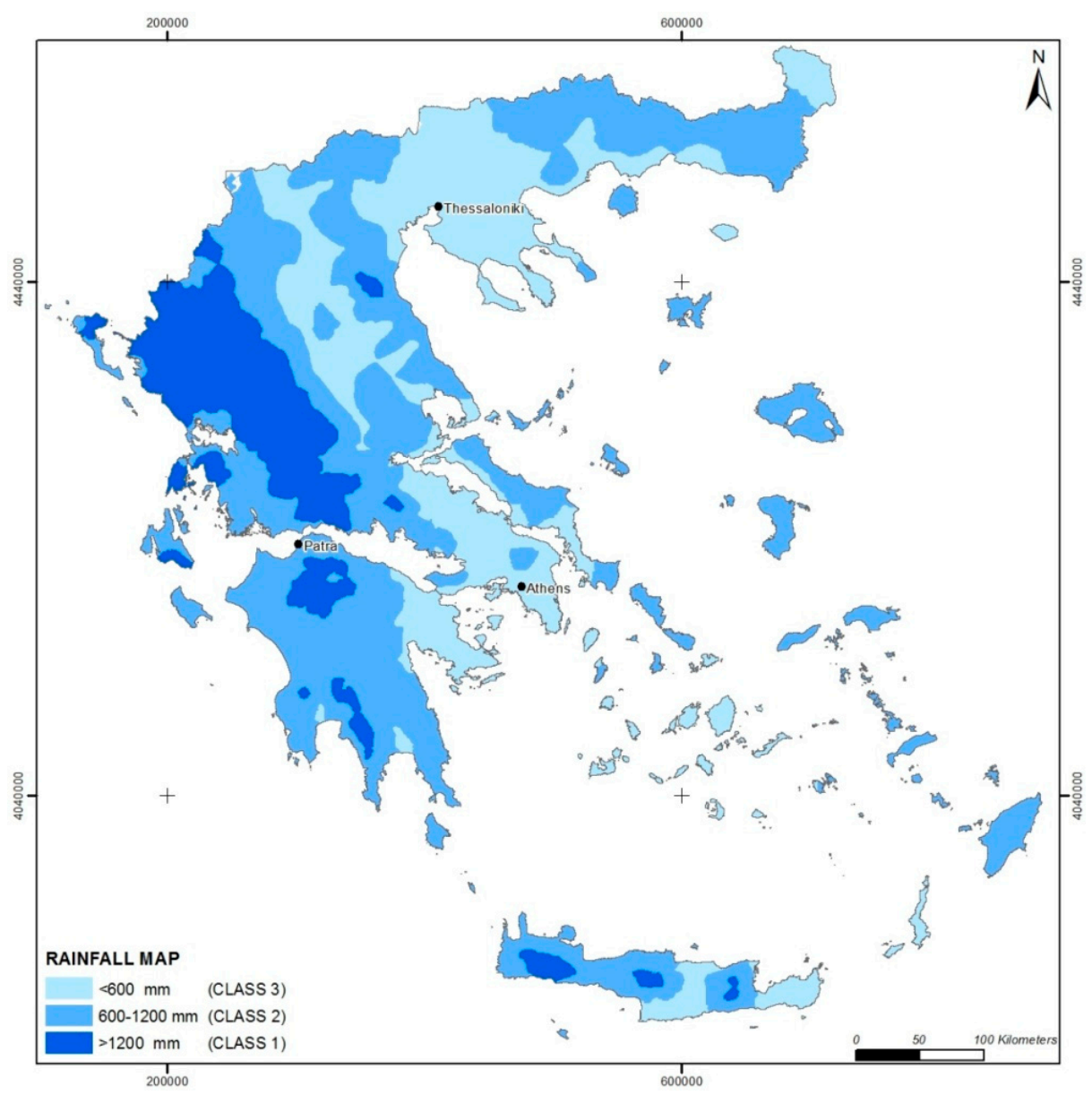

Figure 9. Thematic map of classification of rainfall intensity in Greece.

Table 4. Rating of annual rainfall intensity.

\begin{tabular}{ccc}
\hline Rainfall Intensity (Height of Rainfall per Year) & Rockfall Susceptibility & Class \\
\hline$<600 \mathrm{~mm}$ & Low & 3 \\
$600 \mathrm{~mm}<\mathrm{R}<1200 \mathrm{~mm}$ & Moderate & 2 \\
$>1200 \mathrm{~mm}$ & High & 1 \\
\hline
\end{tabular}

\subsubsection{Earthquake Intensity}

Harp \& Jibson (2002) [56] proposed that concentrated seismically triggered rockfalls may result from local amplification of seismic shaking. In order to take into account the effect of earthquakes on the susceptibility, the rating of the acceleration coefficient was considered. Based on the fact that Greece is characterized by three categories with different acceleration coefficients (EPPO, 2003) [57], a simple rating was proposed for earthquake intensity. This rating is summarized in Table 5 and the classification map is presented in Figure 10.

Table 5. Rating of earthquake intensity.

\begin{tabular}{ccc}
\hline Earthquake Intensity & Rockfall Susceptibility & Class \\
\hline$<0.12 \mathrm{~g}$ & Low & 3 \\
$0.12 \mathrm{~g}<\mathrm{a}<0.24 \mathrm{~g}$ & Moderate & 2 \\
$>0.24 \mathrm{~g}$ & High & 1 \\
\hline
\end{tabular}




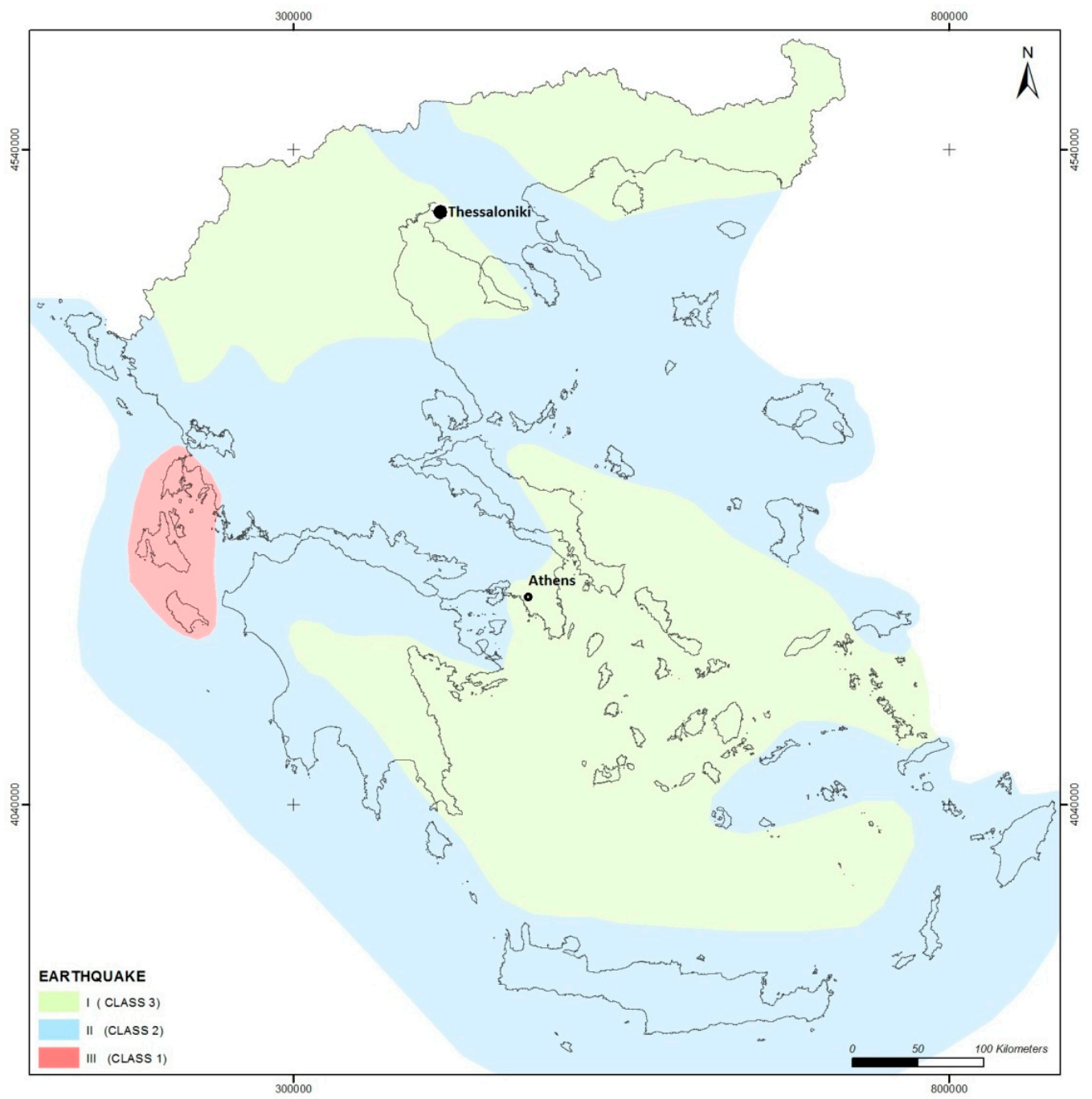

Figure 10. Thematic map of classification of earthquake intensity in Greece.

\subsubsection{Presence of Faults}

Fault zones increase rockfall potential by creating steep slopes and weakened, highly fractured rockmasses. The concept of a fault damage zone has been documented by many authors and a general classification has been published by Kim et al. (2004) [58]. Shipton and Cowie (2003) [59] observed that the damage zone width is approximately 2.5 times the throw, but added that this value is lithology dependent. Brideau et al. (2005) [60] observed that the block size and shape vary as a function of the distance from a fault. The extent of the damage zones that they observed is up to $10 \mathrm{~m}$.

The major faults and thrusts included in the Greek territory have been digitized from the geological map (IGME, scale 1:500.000) and superimposed to form a vector layer. On this layer, a distance function was applied in order to define buffer zones along the structural discontinuities, while two buffer zones, each $250 \mathrm{~m}$ wide, were created. The basis of this selection was considering that the estimated width of influence by the presence of a fault in terms of increased fracturing of a rockmass is $250 \mathrm{~m}$. In order to account for the fault presence in the rockfall susceptibility rating, a value of 1 is attributed when a fault is present within a distance of $250 \mathrm{~m}$ from the rock slope and a value of 0 is attributed when no fault is present. 
Based on the inventory, twenty (20) slopes are related to fault presence and this result in higher rockfall activity. Rondoyanni et al. (2013) [61] has highlighted the importance of presence of active faults on highway slopes in Greece.

\subsection{Susceptibility Map}

The matrix-based approach is described by a simple index, denoted as Rockfall Susceptibility Index (RSI), which is the sum of the class rating of the aforementioned factors according to the following equation:

$$
\mathrm{RSI}=\sum \mathrm{Lr}+\mathrm{Rr}+\mathrm{Er}+\mathrm{Fr}
$$

where: RSI—Rockfall susceptibility index; Lr—lithology; Rr-rainfall intensity; Er-earthquake intensity; $\mathrm{Fr}$-fault presence

Thus, a regional area is more susceptible to rockfalls when the index has lower values. The slope gradient is not summed in the index RSI and when its value is 0 , no rockfall occurs. Rockfall susceptibility is classified in three categories, "low" ( $8 \leq \mathrm{RSI} \leq 9)$, "moderate" ( $5 \leq \mathrm{RSI} \leq 7)$, and "high" ( $3 \leq \mathrm{RSI} \leq 4)$, according to a matrix-based approach for all the possible combinations between the categories of the main factors. The rating matrix is presented in Table 6. It is highlighted, that each factor has an equal weight in the calculation of the total susceptibility index.

Table 6. Rating matrix for the calculation of Rockfall Susceptibility Index (RSI). Category of low susceptibility in grey, moderate in green, and high in red.

\begin{tabular}{|c|c|c|c|}
\hline RSI & Earthquake (class 1) & Earthquake (class 2) & Earthquake (class 3) \\
\hline $\begin{array}{c}\text { Lithology + Rainfall } \\
\text { classes (sum = 2) }\end{array}$ & 3 & 4 & 5 \\
\hline $\begin{array}{c}\text { Lithology + Rainfall } \\
\text { classes (sum = 3) }\end{array}$ & 4 & 5 & 6 \\
\hline $\begin{array}{c}\text { Lithology + Rainfall } \\
\text { classes (sum = 4) }\end{array}$ & 5 & 7 & 8 \\
\hline $\begin{array}{c}\text { Lithology + Rainfall } \\
\text { classes (sum = 5) }\end{array}$ & 6 & 8 & 9 \\
\hline $\begin{array}{c}\text { Lithology + Rainfall } \\
\text { classes (sum = 6) }\end{array}$ & 7 & 6 & 7 \\
\hline
\end{tabular}

The spatial distribution of rockfall susceptibility in Greece, based on this approach, is presented in Figure 11. It forms a basis for spatial prediction of the rockfall triggering areas and it gives a general overview of susceptible areas at a national scale. The results of this approach cannot be accurate if the susceptibility is examined at a local scale, since the resolution of the map is quite low for such purposes. Furthermore, it gives guidance for further and more detailed research studies. 


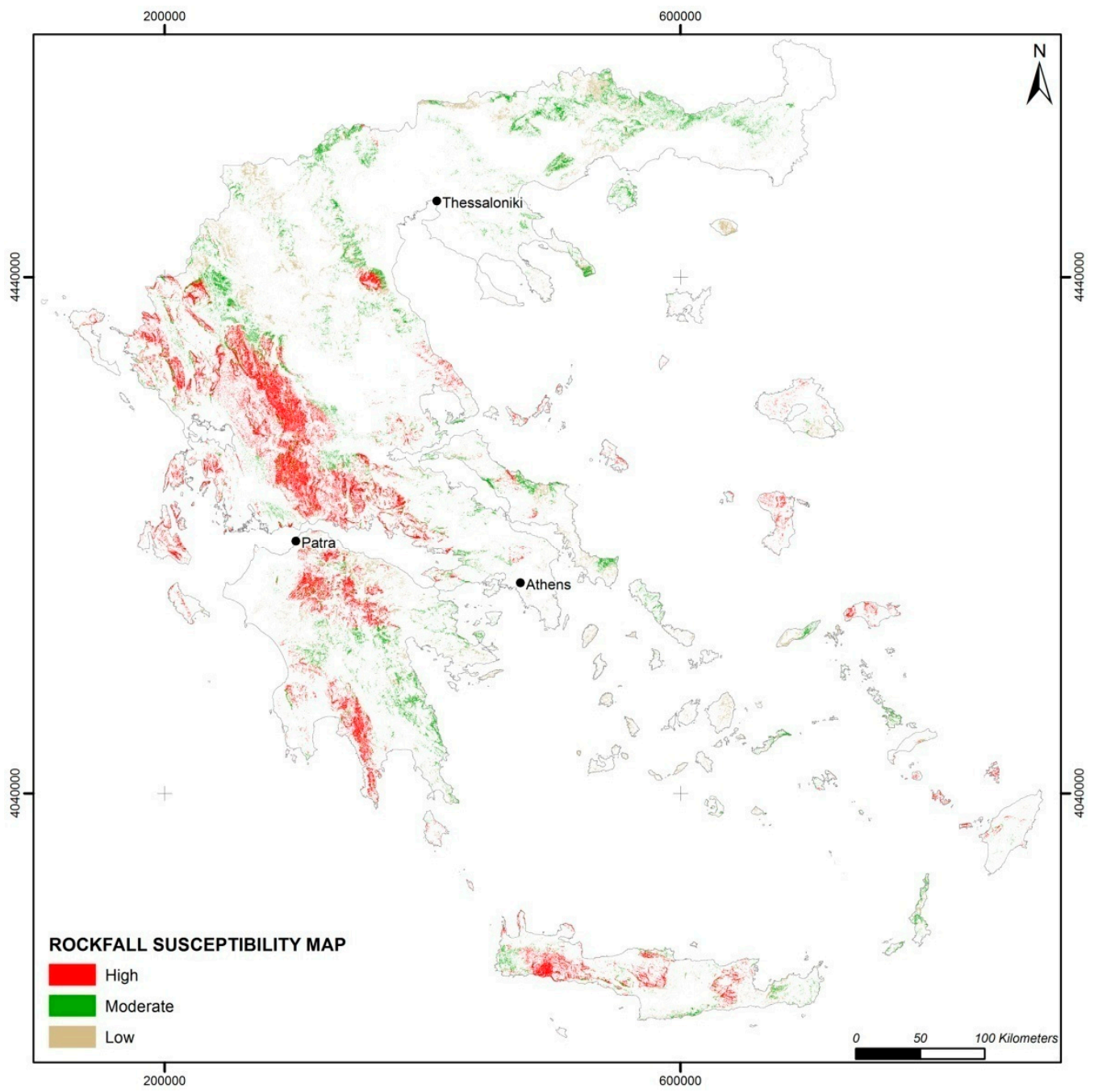

Figure 11. Rockfall susceptibility map of Greece.

\section{Discussion}

In order to check the reliability of the susceptibility zoning map, the data set of the rockfall inventory presented earlier was used. The susceptibility map accompanied by the locations of the rockfall inventory is shown in Figure 12.

It is evident that the majority of the recorded events are encountered in areas characterized as moderately to highly susceptible to rockfalls. Some events (locations no. 1, 8, 20, 23, and 37) are encountered in areas with low susceptibility. This is anticipated, as the resolution of the susceptibility map is relatively low and thus cannot accurately predict the occurrence of a rockfalls at a regional or local scale. For example, the slope gradient in a small area may be very high due to the presence of a steep rock slope (such as in location no. 1), which is not reflected in the DTM used for the preparation of the susceptibility map. 


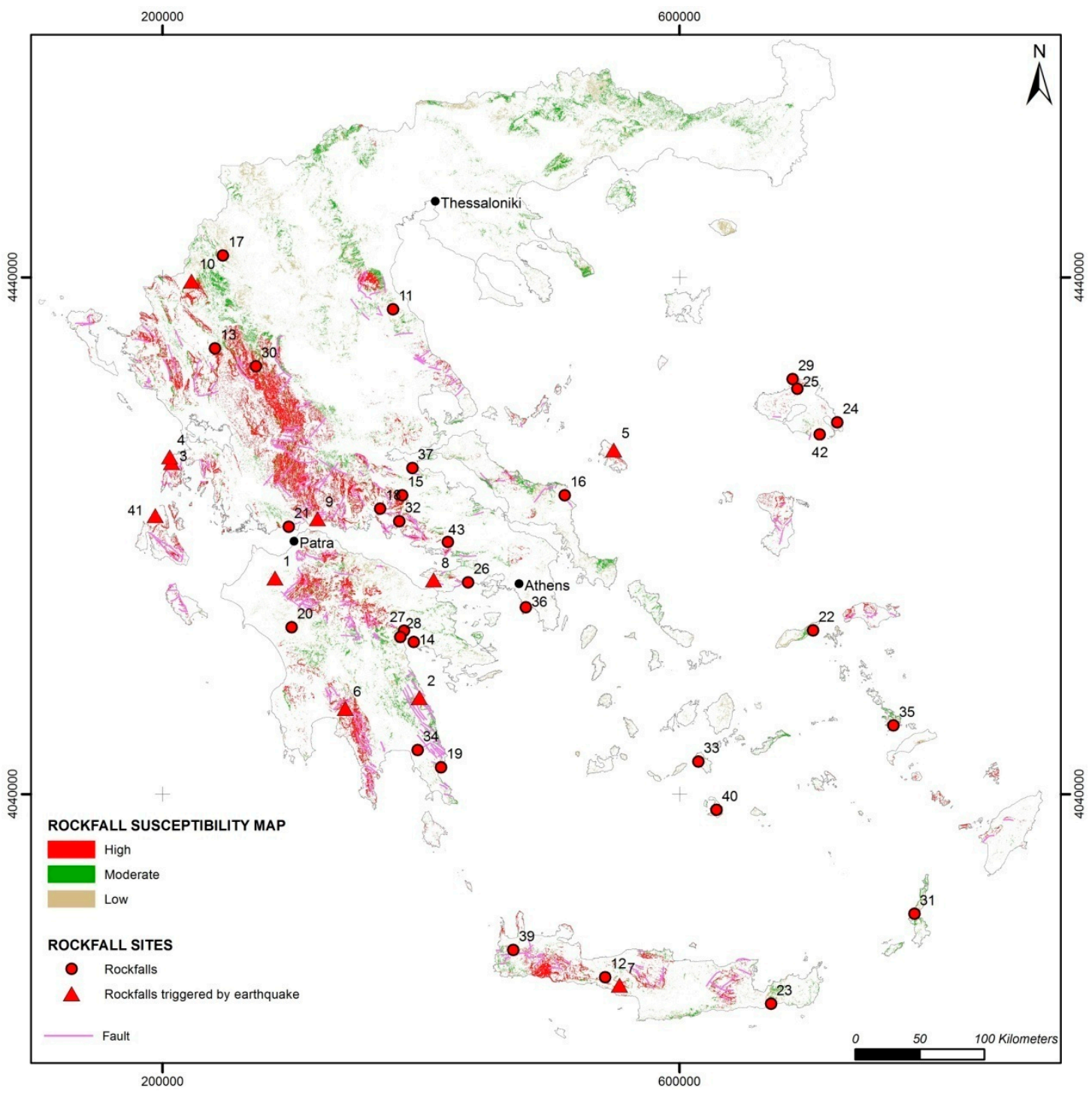

Figure 12. Rockfall susceptibility map and inventory of rockfalls in Greece.

\section{Conclusions}

According to the results of the present research, a rockfall susceptibility zoning map for Greece was prepared based on a simple Rockfall Susceptibility Index (RSI). This index is based on the rating of the (a) slope gradient, (b) slope lithology, (c) rainfall intensity, (d) earthquake intensity, and (e) fault presence. The map forms a basis for spatial prediction of rockfall-prone areas at a national scale, while it provides guidance for further and more detailed investigation at the regional scale. It also represents areas exposed to rockfalls and provides the first necessary information towards land use decisions by governmental administrations. Another benefit is that it can assist in the detection of human infrastructure located in susceptible areas which require further analysis, such as hazard and risk.

The reliability of the susceptibility zoning map was checked using a data set of sixty (60) rockfall events for the period between 1935 and 2019. Validation against an independent dataset could be carried out in the future, when new data from rockfalls will be available. Based on the analysis of the recorded data from this inventory, it was evident that the number of rockfalls has increased in recent years.

It was also evident that the main triggering factor was rainfall (33\%), while the second most frequent triggering mechanism was earthquake loading (25\%). Emphasis was given to investigate the 
possible presence of faults in rockfall-prone areas and it was shown that half of the rockfall events occurred in slopes were fault scarps exist.

The effect of earthquakes as a triggering mechanism; in particular, the relation with epicenter distance and magnitude of earthquake was also studied. It was found that coseismic rockfall events in Greece were triggered by earthquakes of magnitude between $\mathrm{M}_{\mathrm{w}}=5.7$ and 6.7, while the distance from the epicenter to a reported rockfall was between 3 and $37 \mathrm{~km}$.

The impact of rockfalls was severe in most cases, mainly resulting in damage to roads and houses ( $32 \%$ and $20 \%$ of the total events respectively), while few events resulted in casualties. The potential risk to archaeological sites is also quite high ( $11 \%$ of the total events).

The present study was the first comprehensive study on the occurrence of rockfalls in Greece. It provides a susceptibility zoning assessment at a national scale based on the most important factors, which can prove a valuable decision support tool against rockfall hazards.

Acknowledgments: The author would like to thank I.G.M.E. for providing data from technical reports on rock slope instabilities and I. Kalogeras, National Observatory of Athens for providing data on the studied earthquakes in Greece. The assistance of E. Lykoudi in the preparation of GIS maps is gratefully acknowledged.

Conflicts of Interest: The authors declare no conflict of interest.

\section{References}

1. Mason, P.J.; Rosenbaum, M.S. Geohazard mapping for predicting landslides: An example from the Langhe Hills in Piemonte, NW Italy. Q. J. Eng. Geol. Hydrogeol. 2002, 35, 317-326. [CrossRef]

2. Mancini, F.; Ce-ppi, C.; Ritrovato, G. GIS and statistical analysis for landslide susceptibility mapping in the Daunia area, Italy. Nat. Hazard Earth Syst. Sci. 2010, 10, 1851-1864. [CrossRef]

3. Calvello, M.; Cascini, L.; Mastroianni, S. Landslide zoning over large areas from a sample inventory by means of scale-dependent terrain units. Geomorphology 2013, 182, 33-48. [CrossRef]

4. Carrara, A.; Cardinalli, M.; Detti, R.; Guzzetti, F.; Pasqui, V.; Reichenbach, P. GIS Techniques and statistical models in evaluating landslide hazards. Earth Surf. Process Landf. 1991, 16, 427-445. [CrossRef]

5. Barredo, J.J.; Benavides, A.; Hervas, J.; Van Western, C.J. Comparing heurisitc landslide hazard assessment techniques using GIS in the Trijana basin, Gran Canaria Island, Spain. Int. J. Appl. Earth Obs. Geoinf. 2000, 2, 9-23. [CrossRef]

6. Fernandez, T.; Irigaray, C.; Hamdouni, R.E.; Chacon, J. Methodology for landslide susceptibility mapping by means of a GIS, application to the Contraviesa Area (Granada, Spain). Nat. Hazards 2003, 30, 297-308. [CrossRef]

7. Kolat, C.; Doyuran, V.; Ayday, C.; Suzen, M.L. Preparation of a geotechnical microzonation model using GIS Systems based on Multicriteria decision Analysis. Eng. Geol. 2006, 87, 241-255. [CrossRef]

8. Yilmaz, I.; Yildirim, M. Structural and geomorphological aspects of the Kat landslides (Tokat-Turkey) and susceptibility mapping by means of GIS. Environ. Geol. 2006, 50, 461-472. [CrossRef]

9. Nandi, A.; Shakoor, A. A GIS-based landslide susceptibility evaluation using bivariate and multivariate statistical analyses. Eng. Geol. 2009, 110, 11-20. [CrossRef]

10. Paulin, G.L.; Bursik, M.; Hubp, J.L.; Mejia, L.M.P.; Quesada, F.A. A GIS method for landslide inventory and susceptibility mapping in the Rio El Estado watershed, Pico de Orizaba volcano, Mexico. Nat. Hazards 2014, 71, 229-241. [CrossRef]

11. Brabb, E.E. Innovative approaches to landslide hazard mapping. In Proceedings of the 4th International Symposium on Landslides, Toronto, ON, Canada, 16-21 September 1984; Volume 1, pp. 307-324.

12. Guzzetti, F.; Reichenbach, P.; Ardizzone, F.; Cardinali, M.; Galli, M. Estimating the quality of landslide susceptibility models. Geomorphology 2006, 81, 166-184. [CrossRef]

13. Ferrari, F.; Giacomini, A.; Thoeni, K. Qualitative rockfall hazard assessment: A comprehensive review of current practices. Rock Mech. Rock Eng. 2016, 49, 2865-2922. [CrossRef]

14. Fell, R.; Corominas, J.; Bonnard, C.; Cascini, L.; Leroi, E.; Savage, W.Z. Guidelines for landslide susceptibility, hazard and risk-zoning for land use planning. Eng. Geol. 2008, 102, 85-98. [CrossRef] 
15. Chau, K.T.; Wong, R.H.C.; Liu, J.; Lee, C.F. Rockfall hazard analysis for Hong Kong based on rockfall inventory. Rock Mech. Rock Eng. 2003, 36, 383-408. [CrossRef]

16. Chau, K.T.; Tang, Y.F.; Wong, R.H.C. GIS based rockfall hazard map for Hong Kong. Int. J. Rock Mech. Min. Sci. 2004, 41, 846-851. [CrossRef]

17. Čarman, M.; Kumelj, S.; Komac, M.; Ribicic, M. Rockfall susceptibility map of Slovenia. In Proceedings of the Interdisciplinary Rockfall Workshop, Innsbruck, Austria, 16-19 May 2011.

18. Trigila, A.; Frattini, P.; Casagli, N.; Catani, F.; Crosta, G.; Esposito, C.; Iadanza, C.; Lagomarsino, D.; Mugnozza, G.S.; Segoni, S.; et al. Landslide susceptibility mapping at national scale: The Italian case study. In Landslide Science and Practice; Springer: Berlin/Heidelberg, Germany, 2013; pp. 287-295.

19. Günther, A.; Reichenbach, P.; Malet, J.P.; Van Den Eeckhaut, M.; Hervás, J.; Dashwood, C.; Guzzetti, F. Tier-based approaches for landslide susceptibility assessment in Europe. Landslides 2013, 10, 529-546. [CrossRef]

20. Koukis, G.; Sabatakakis, N.; Nikolaou, N.; Loupasakis, C. Landslide Hazard Zonation in Greece; Sassa, K., Fukuoka, H., Wang, F., Wang, C., Eds.; Springer: Berlin/Heidelberg, Germany, 2005; pp. 291-296.

21. Sabatakakis, N.; Koukis, G.; Vassiliades, E.; Lainas, S. Landslide susceptibility zonation in Greece. Nat. Hazards 2013, 65, 523-543. [CrossRef]

22. Antoniou, A.A.; Lekkas, E. Rockfall susceptibility map for Athinios port, Santorini island, Greece. Geomorphology 2010, 118, 152-166. [CrossRef]

23. Papazachos, B.C.; Papazachou, C. The Earthquakes of Greece; Editions ZITI: Thessaloniki, Greece, 1997; 304p.

24. Pavlides, S.; Caputo, R. Tectonophysics Magnitude versus fault's surface parameters: Quantitative relationships from the Aegean Region. Tectonophysics 2004, 380, 159-188. [CrossRef]

25. Ambraseys, N.N.; Jackson, J.A. Seismicity and associated strain of central Greece between 1890 and 1988. Geophys. J. Int. 1990, 101, 663-708. [CrossRef]

26. Saroglou, H. Rockfall hazard in Greece. Bull. Geol. Soc. Greece 2013, 47, 1429-1438. [CrossRef]

27. Papathanassiou, G.; Valkaniotis, S.; Ganas, A.; Pavlides, S. GIS-based statistical analysis of the spatial distribution of earthquake-induced landslides in the island of Lefkada, Ionian Islands, Greece. Landslides 2013, 10, 771-783. [CrossRef]

28. Zygouri, V.; Koukouvelas, I.K. Evolution of rock falls in the Northern part of the Peloponnese, Greece. IOP Conf. Ser. Earth Environ. 2015, 26, 012043. [CrossRef]

29. Saroglou, H.; Asteriou, P.; Tsiambaos, G.; Manousakis, J.; Zekkos, D. Study of co-seismic rockfalls during Lefkada and Cephallonia Earthquakes, Greece. In Proceedings of the 3rd North American Symposium on Landslides, Roanoke, VA, USA, 4-8 June 2017; pp. 521-528.

30. Saroglou, H.; Asteriou, P.; Zekkos, D.; Tsiambaos, G.; Clark, M.; Manousakis, J. UAV-based mapping, back analysis and trajectory modeling of a coseismic rockfall. Nat. Hazards Earth Syst. Sci. 2018, 18, 321-333. [CrossRef]

31. Koukis, G.; Ziourkas, C. Slope instability phenomena in Greece: A statistical analysis. Bull. Int. Assoc. Eng. Geol. 1991, 43, 47-60. [CrossRef]

32. Sartori, M.; Baillifard, F.; Jaboyedoff, M.; Rouiller, J.-D. Kinematics of the 1991 Randa rockslides (Valais, Switzerland). Nat. Hazards Earth Syst. Sci. 2003, 3, 423-433. [CrossRef]

33. Marquínez, J.; Menéndezduarte, R.; Farias, P.; Jiménez Sánchez, M. Predictive GIS-based model of rockfall activity in mountain Cliffs. Nat. Hazards 2003, 30, 341-360. [CrossRef]

34. Dorren, L.; Seijmonsbergen, A. Comparison of three GIS-based models for predicting rockfall runout zones at a regional scale. Geomorphology 2003, 56, 49-64. [CrossRef]

35. Nikolaou, N.; Pogiatzi, E.; Spanos, N. Report on Landslides in Greece on 2010; I.G.M.E. (Instituto Geologico y Minero de Espana): Madrid, Spain, 2011; p. 8.

36. Gorum, T.; Fan, X.; van Westen, C.J.; Huang, R.Q.; Xu, Q.; Tang, C.; Wang, G. Distribution pattern of earthquake-induced landslides triggered by the 12 May 2008 Wenchuan earthquake. Geomorphology 2011, 133, 152-167. [CrossRef]

37. Wasowski, J.; Del Gaudio, V. Evaluating seismically induced mass movement hazard in Caramanico Terme (Italy). Eng. Geol. 2000, 58, 291-311. [CrossRef] 
38. Rodriguez-Peces, M.J.; Garcia-Mayordomo, J.; Azanon, J.; Jabaloy, A. Regional Hazard Assessment of Earthquake-Triggered Slope Instabilities considering Site Effects and Seismic Scenarios in Lorca Basin (Spain). Environ. Eng. Geosci. 2011, 17, 183-196. [CrossRef]

39. Marzorati, S.; Luzi, L.; De Amicis, M. Rock falls induced by earthquakes: A statistical approach. Soil Dyn. Earthq. Eng. 2002, 22, 565-577. [CrossRef]

40. Keefer, D.K. Landslides caused by earthquakes. Bull. Geol. Soc. Am. 1984, 95, 406-421. [CrossRef]

41. Rodriguez, C.E.; Bommer, J.J.; Chandler, R.J. Earthquake induced landslides: 1980-1997. Soil Dyn. Earthq. Eng. 1999, 18, 325-346. [CrossRef]

42. Papadopoulos, G.A.; Plessa, A. Magnitude-distance relations for earthquake-induced landslides in Greece. Eng. Geol. 2000, 58, 377-386. [CrossRef]

43. Chousianitis, K.; Del Gaudio, V.; Sabatakakis, N.; Kavoura, K.; Drakatos, G.; Bathrellos, G.D.; Skilodimou, H.D. Assessment of Earthquake-Induced Landslide Hazard in Greece: From Arias Intensity to Spatial Distribution of Slope Resistance Demand. Bull. Seismol. Soc. Am. 2016, 106, 174-188. [CrossRef]

44. Marinos, P.; Kavvadas, M.; Tsiambaos, G.; Saroglou, H. Rock slope stabilization in Mythimna castle, Lesvos island, Greece. In Proceedings of the 1st European Conference on Landslides, Prague, Czech Republic, 24-26 June 2002; pp. 635-639.

45. Koukouvelas, I.; Litoseliti, A.; Nikolakopoulos, K.; Zygouri, V. Earthquake triggered rock falls and their role in the development of a rock slope: The case of Skolis Mountain, Greece. Eng. Geol. 2015, 191, 71-85. [CrossRef]

46. Saroglou, H.; Berger, F.; Bourrier, F.; Asteriou, P.; Tsiambaos, G.; Tsagkas, D. Effect of forest presence on rockfall trajectory. An example from Greece. In Proceedings of the 12th International Congress of IAEG, Torino, Italy, 13-19 September 2015.

47. Christaras, B.; Vouvalidis, K. Rockfalls in the archaeological site of Delphi, Greece. In Proceedings of the IAEG 2010 International Congress, Auckland, New Zealand, 5-10 September 2010.

48. Marinos, P.; Tsiambaos, G. Earthquake triggering rock falls affecting historic monuments and a traditional settlement in Skyros Island, Greece. In Proceedings of the International Symposium: Landslide Risk Mitigation and Protection of Cultural and Natural Heritage, Kyoto, Japan, 21-25 January 2002; pp. 343-346.

49. Saroglou, H.; Marinos, V.; Marinos, P.; Tsiambaos, G. Rockfall hazard and risk assessment: An example from a high promontory at the historical site of Monemvasia, Greece. Nat. Hazards Earth Syst. Sci. 2012, 12, 1823-1836. [CrossRef]

50. Gupta, R.P.; Saha, A.K.; Arora, M.K.; Kumar, A. Landslide Hazard Zonation in part of the Bhagirathi Valley, Garhwal Mimalyas, using integrated remote sensing-GIS. Himal. Geol. 1999, 20, 71-85.

51. Meisina, C.; Piccio, A.; Tocchio, A. Some aspects of the landslide susceptibility in the Sorba Valley (western Alps, Italy). In Proceedings of the International Conference on Landslides-Causes, Impacts and Countermeasures, Davos, Switzerland, 17-21 June 2001; Kuhne, M., Einstein, H.H., Krauter, E., Klapperich, H., Pottler, R., Eds.; VGE: Essen, Germany, 2001; pp. 547-556.

52. Baillifard, F.; Jaboyedoff, M.; Sartori, M. Rockfall hazard mapping along a mountainous road in Switzerland using a GIS-based parameter rating approach. Nat. Hazards Earth Syst. Sci. 2003, 3, 431-438. [CrossRef]

53. Coe, J.A.; Harp, E.L. Influence of tectonic folding on rockfall susceptibility, American Fork Canyon, Utah, USA. Nat. Hazards Earth Syst. Sci. 2007, 7, 1-14. [CrossRef]

54. Fityus, S.G.; Giacomini, A.; Buzzi, O. The significance of geology for the morphology of potentially unstable rocks. Eng. Geol. 2013, 162, 43-52. [CrossRef]

55. Krautblatter, M.; Moser, M. A nonlinear model coupling rockfall and rainfall intensity based on a four year measurement in a high Alpine rock wall (Reintal, German Alps). Nat. Hazards Earth Syst. Sci. 2009, 9, 1425-1432. [CrossRef]

56. Harp, E.L.; Jibson, R.W. Anomalous concentrations of seismically triggered rock falls in Pacoima Canyon: Are they caused by highly susceptible slopes or local amplification of seismic shaking. Bull. Seismol. Soc. Am. 2002, 92, 180-189. [CrossRef]

57. EPPO. Greek Seismic Code; Earthquake Planning and Protection Organization: Athens, Greece, 2003.

58. Kim, Y.-S.; Peacock, D.C.; Sanderson, D.J. Fault damage zones. J. Struct. Geol. 2004, 26, 503-517. [CrossRef]

59. Shipton, Z.K.; Cowie, P.A. A conceptual model for the origin of fault damage zone structures in high-porosity sandstone. J. Struct. Geol. 2003, 25, 333-344. [CrossRef] 
60. Brideau, M.A.; Stead, D.; Kinakin, D.; Fecova, K. Influence of tectonic structures on the Hope Slide, British Columbia, Canada. Eng. Geol. 2005, 80, 242-259. [CrossRef]

61. Rondoyanni, T.; Lykoudi, E.; Triantafyllou, A.; Papadimitriou, M.; Foteinos, I. Active faults affecting linear engineering projects: Examples from Greece. Geotech. Geol. Eng. 2013, 31, 1151-1170. [CrossRef] 